\title{
Suspension Dosage Form
}

National Cancer Institute

\section{Source}

National Cancer Institute. Suspension Dosage Form. NCI Thesaurus. Code C42994.

Insoluble solid particles composed of active and/or inert ing redient(s) that are dispersed in a liquid. 